all persons who have a major professional interest in economics as applied to producing, harvesting, processing, marketing, or consumption of forest products or services.

Registration forms for the directory were mailed during the first week in September to all forest and forest-industry economists of record. Those who do not receive forms but who wish to be included in the directory are asked to write to the chairman of the directory committee: William $A$. Duerr, State University College of Forestry, Syracuse, New York, U.S.A. 13210.

The purposes of the forestry economics directory are (1) to identify workers in the field so that they can communicate more readily with one another and thus promote the unity and the development of the field; (2) to help research workers, prospective employers, program chairman for professional meetings, government agencies or industrial concerns in search of advisers, and others who may need to know who is working in the field or in special parts of the field; and (3) to provide a mailing list for specialized professional material.

\title{
S. A. F. to MeEt in Denver
}

With an expected attendance of 1200 professional foresters and guests, the 64th annual meeting of the Society of American Foresters will be held September 27-30 in Denver, Colo., at the Hilton Hotel. The meeting theme is "Forestry at the Top of the Nation." Philip A. Briegleb, president of the Society, has announced that all foresters and friends of forestry everywhere are welcome to attend.

General chairman for the meeting, D. S. Nordwall, U.S. Forest Service regional forester at Denver, has announced the keynote speakers for the opening session.

Depicting multiple use values of the Rocky Mountain region will be Fred Kennedy, regional forester at Albuquerque, N. Mex., talking about "Our Last Forest Frontier." Harry Woodward, director of Colorado Game, Fish, and Parks Department, will speak about "Rocky Mountains-The Quintessence of Outdoor Recreation." The director of research at Potlatch Forest Industries. Inc., Herbert B. McKean, will discuss "Forestry Research-An Essential to Mature and Successful Land Management in the Rockies."

Following the opening session and a Society affairs session on September 28,70 papers will be presented in eleven technical sessions on September 29 and 30. These sessions will be concerned with forest economics and policy, forestry education, forest fire, forest management, forest mensuration, forest products, forest recreation, forest-wildlife management, range management, silviculture, and watershed management. 